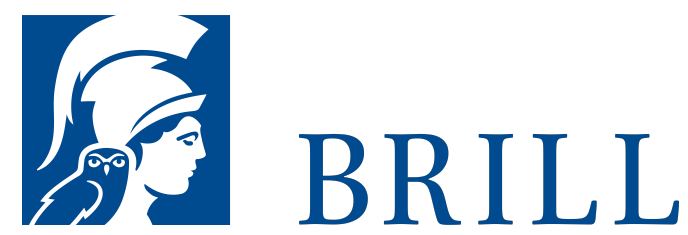

\title{
Die jüdische Gesellschaft in Kurland und Riga 1795-1915
}

Author: Svetlana Bogojavlenska

Angeregt von der gesellschaftlichen Diskussion über die Wurzeln des Antisemitismus in Lettland, verfolgt die Autorin die Geschichte der jüdischen Minderheit im Gouvernement Kurland und in Riga in der Zeit zwischen der Dritten Teilung Polens 1795 und der Zwangsaussiedlung der Juden aus Kurland 1915.

Die Darstellung berücksichtigt dabei insbesondere die Bedeutung der durch das Russische Reich gesetzten Rahmenbedingungen, die politische und kulturelle Dominanz der Deutschen im Baltikum sowie die Rolle der seit Mitte des 19. Jahrhunderts stark anwachsenden lettischen Nationalbewegung.

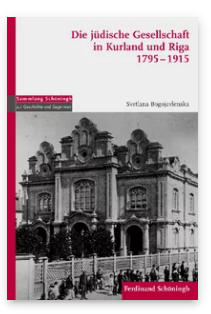

Pages: 243

Seiten, $17 \mathrm{~s} / \mathrm{w}$

Abb., 1 s/w Tab.

Language:

German

Subjects: Early

Modern History, History

Publisher: Brill | Schöningh

Series:

Sammlung

Schöningh zur

Geschichte und

Gegenwart

E-Book (PDF)

Released online:

22 Jan 2013

ISBN: $978-3^{-}$

657-77128-8

List price

USD $\$ 60.00$

Hardback

Publication date: O2 Apr 2012

ISBN: 978-35०6-77128-5

List price

USD \$60.00 
Svetlana Bogojavlenska, Dr. phil., geb. 1977, Studium der Geschichte und Philosophie in Riga und Mainz; 1977-2002 wiss. Mitarbeiterin und Leiterin der Sammlung des Museums »Juden in Lettland «, Riga. Seit 2003 als wiss. Mitarbeiterin und Lehrbeauftragte an der Universität Mainz tätig; seit April 2011 Stipendiatin des Landes Rheinland-Pfalz.

For more information see brill.com

Order information: Order online at brill.com +44330 3330049 | customerservices@brill.com Submission information: brill.com/authors

Titles published by Brill | Fink, Brill | mentis or Brill | Schöningh: +49(o)715413279216| brill@brocom.de 